\title{
Armenia in Ptolemy's Geography (CA. AD 150): A "PARody" of His Work? Some Corrections and Suggestions
}

\author{
Klaus Geus \\ iD http:/orcid.org/0000-0003-1758-9061 \\ Freie Universität Berlin
}

\begin{abstract}
Ptolemy's Geographike Hyphegesis (Introduction to Geography) (ca. AD 150) consists of a huge and invaluable stock of topographical information. More than 6,000 toponyms are even defined by coordinates. Nevertheless, Ptolemy's cities are often misplaced or pop up more than once in his maps. This is especially true with his confusing description of Armenia (geogr. 5.13), which caused a modern scholar to call it a 'parody' of his work and method. This paper aims at clarifying the basic error in all of Ptolemy's coordinates and proposes some explanations and corrections for his Armenian toponyms.
\end{abstract}

Keywords: Ptolemy, ancient Armenia, ancient geography, cartography.

\section{Introduction}

This paper focuses on a strange paradox: on the one hand, Ptolemy's Geography (ca. AD 150) has - by far - the most Armenian toponyms in any ancient text; Ptolemy even informs us about the coordinates for 85 cities $^{1}$ in Greater Armenia ${ }^{2}$ (5.13); on the other

1 Ptolemy adds 21 pairs of coordinates for other locations like sources, bends or mouths of rivers, lakes, end points of mountains, and border points with other countries.

2 According to Ptolemy, the boundaries of Greater Armenia are defined counter-clockwise in the north by the Kyros river from its mouth $\left(79^{\circ} 40^{\prime} / 44^{\circ} 30^{\prime}[5.12 .1-2 ; 5.13 .1 .3]\right)$ to its confluence with the Araxes $\left(78^{\circ} 30^{\prime} / 44^{\circ} 30^{\prime}[5.13 .6]\right)$ to the end point of Albania and Iberia at Zalissa $\left(76^{\circ} / 44^{\circ} 40^{\prime}\right.$ [5.11.1]) to the end point of Iberia and Kolchis at Zadris (74 / 44 $30^{\prime}$ [5.10.3]), by a part of the southern border of Kolchis (5.10.3); in the west by a line along the Moschika mountains (northern end point at $73^{\circ} / 44^{\circ} 45^{\prime}$ [5.6.1]) to the "most northern" bend of the Euphrates river $\left(71^{\circ} / 42^{\circ} 30^{\prime}\right.$ [5.6.1]), following the course of the Euphrates river (5.13.2. 6) downstream, in the south by a line along the Tauros mountains from the Euphrates river $\left(71^{\circ} 40^{\prime} / 38^{\circ}[5.13 .4]\right)$ to the Tigris river $\left(75^{\circ} 30^{\prime} / 38^{\circ} 30^{\prime}\right)$ [5.13.4]) and along the Niphates mountains (5.13.4) from the Tigris river to its end point at the Kaspian mountains (i.e. the end point of Armenia, Media, and Assyria at $80^{\circ} 30^{\prime} / 40^{\circ}$ [5.13.3.4]); in the east by a line along the Kaspian mountains (second end 
hand, these toponyms and coordinates are quite confusing, as the majority has not been identified yet, and even the rest seems to be more or less misplaced. Obviously, Ptolemy draws on an invaluable stock of geographical data, but this data is somehow garbled.

In the following, I shall try to shed some light on this paradox. Firstly, Ptolemy's image of Armenia will be discussed. Is it really a 'parody' of his work and method, as has been proposed? Secondly, an attempt to explain the real problem underlying Ptolemy's coordinates will be made. This will lead to a discussion of how to approach Ptolemy's coordinates. All of this is 'work-in-progress' and I shall present a general approach to the topic in the following. Some examples regarding Greater Armenia will, however, be presented (ch. 4). In the final chapter, the preliminary findings will be summarised outlining a possible approach to further research.

\section{Ptolemy's Image of Armenia: "Almost a Parody" of His Work and Method? The status quaestionis}

Nearly forty years ago the well-known historical geographer Robert Hewsen expressed
the communis opinio on Ptolemy's description of Armenia in this way:

The inaccuracy of Ptolemy's Geography in his description of the Roman Empire is well known but his errors are necessarily worse when he is dealing with regions beyond the imperial frontiers. This is particularly noticeable in his chapter on Armenia. Although his depictions of Lesser Armenia, Colchis, Iberia and Albania are reasonably accurate for Ptolemy, his map of Greater Armenia contains a distortion of its topography which rivals the worst part of his work [my emphasis]. Considering the Roman campaigns of Pompey and Corbulo, the importance of the trade routes which crossed the Armenian plateau, and the conversion of Armenia into a Roman

point at $79^{\circ} / 42^{\circ} 30^{\prime}[5.13 .3 .4]$ ), the border to Media and the Hyrkanian Sea from the Kaspian Mountains to another end point (i.e. the intersection point of the coastline of the Hyrkanian Sea and the borders of Media and Armenia at $79^{\circ} 45^{\prime} / 43^{\circ} 20^{\prime}$ [5.13.3]) and, finally, to the mouth of the Kyros river $\left(79^{\circ} 45^{\prime} / 43^{\circ}\right.$ 20' [5.13.3]). There are two problems with the western border of Armenia. Firstly, according to Ptolemy (5.13.2), Armenia is bordering on Kappadokia "along the (already) described part of the river Euphrates and the described part of the Kappadokian Pontos to Kolchis by the line along the Moschika Mountains." But in 5.6.7 he places the sources of the river Apsorros at $72^{\circ} 45^{\prime} / 43^{\circ}$, i.e. in the east of the Moschika Mountains, and makes them, therefore, a part of Armenia, not Kappadokia. The Bern edition tries to solve the problem by drawing the mountains as a double bent. But as Ptolemy is clearly speaking of a line $\gamma \rho \alpha \operatorname{\mu r} \mu \alpha$ (and contrary to his usual habit, gives no indication of a change of direction), there remain some doubts. As the whole passage seems to be garbled (e.g., some editors changed the name of river from Ampsorros to Glaukos or inserted an additional line on the sources of the river Lykos), I stick to the received text and map the northwestern corner slightly differently than the Bern edition. Probably, the problem resulted from the fact that the coordinates of the Glaukos river dropped out from the Armenia chapter during the process of transmission and were inserted only later by a copyist into the Kappadokia chapter (because of the mention of the river's entry into the Apsorros in 5.6.7), thus causing even more confusion (for a similar case with the sources of the Tigris river, see infra). Secondly, Ptolemy speaks only of Kappadokia in the west of Armenia (5.13.2), but not of Lesser Armenia, where most of the cities lying at the Euphrates are mentioned (5.7.2. 5. 9. 11). Obviously, he considers 'Lesser Armenia' to be a part of Kappadokia (Armenia Minor was incorporated into the Roman province Cappadocia ca. AD 71/72). On a side note: the maps on Asia in the Bern edition exhibit several of the cities "lying at the Euphrates" quite far from the river to the west (e.g., Daskusa [5.7.2] and Barzalo [5.7.12]) or the east (e.g., Marde [6.1.3]). 
province for three years within Ptolemy's lifetime, there appears to be no reason for a description seemingly so chaotic [my emphasis] as to amount to almost a parody on the earlier chapters of the work and of the entire method [my emphasis] by which they were prepared. Despite the many problems [my emphasis] of Ptolemy's map of Armenia, however, there is still a great deal that can be done ... (Hewsen 1982, 111). ${ }^{3}$

Basically, Hewsen's evaluation of Ptolemy's chapter sums up the paradox to which I have already pointed. Considering the amount of information on Armenia which was even greater than for most adjacent regions and which was clearly available to Ptolemy, his description of the region seems to be very poor and chaotic.

Useful for comparison is the sketch in the Armenian atlas of Harut yunyan - Mkhitaryan 2005, 34 (Fig. 1).

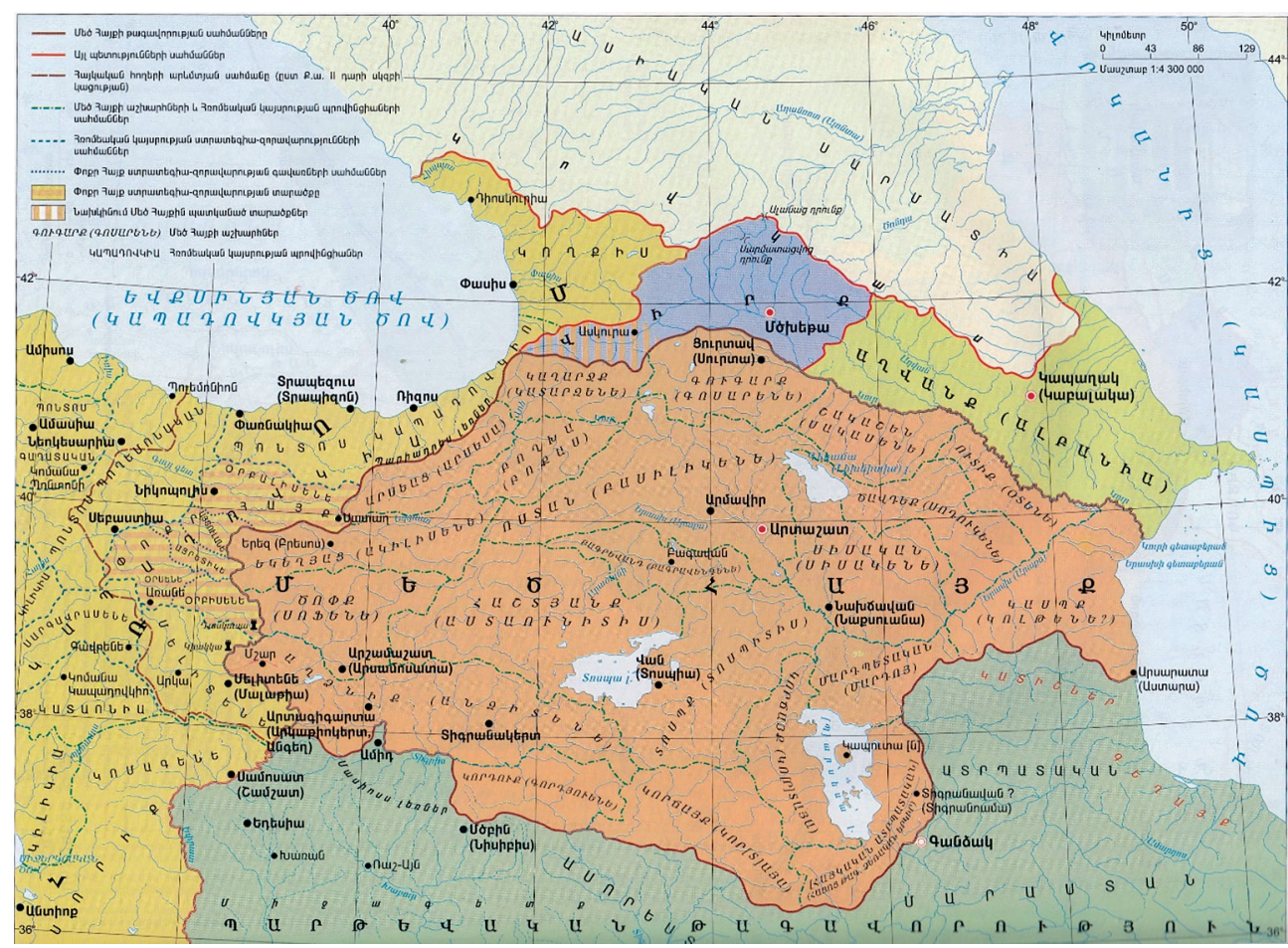

Fig. 1. Ptolemy's Greater Armenia (the presumed boundaries and major cities are plotted onto a modern map)

3 Hewsen 1982, 111 adds: “... and a certain amount of work has already been accomplished in identifying the various toponyms found in the text. In this study, an attempt will be made to identify still more of the locations involved by using a somewhat new approach and, if much that will stated has already appeared in the work of Mueller and other specialists, it is included here because it is necessary for an understanding of the whole." This sentiment is mirrored (without mentioning Hewsen) by Licini 2017. 


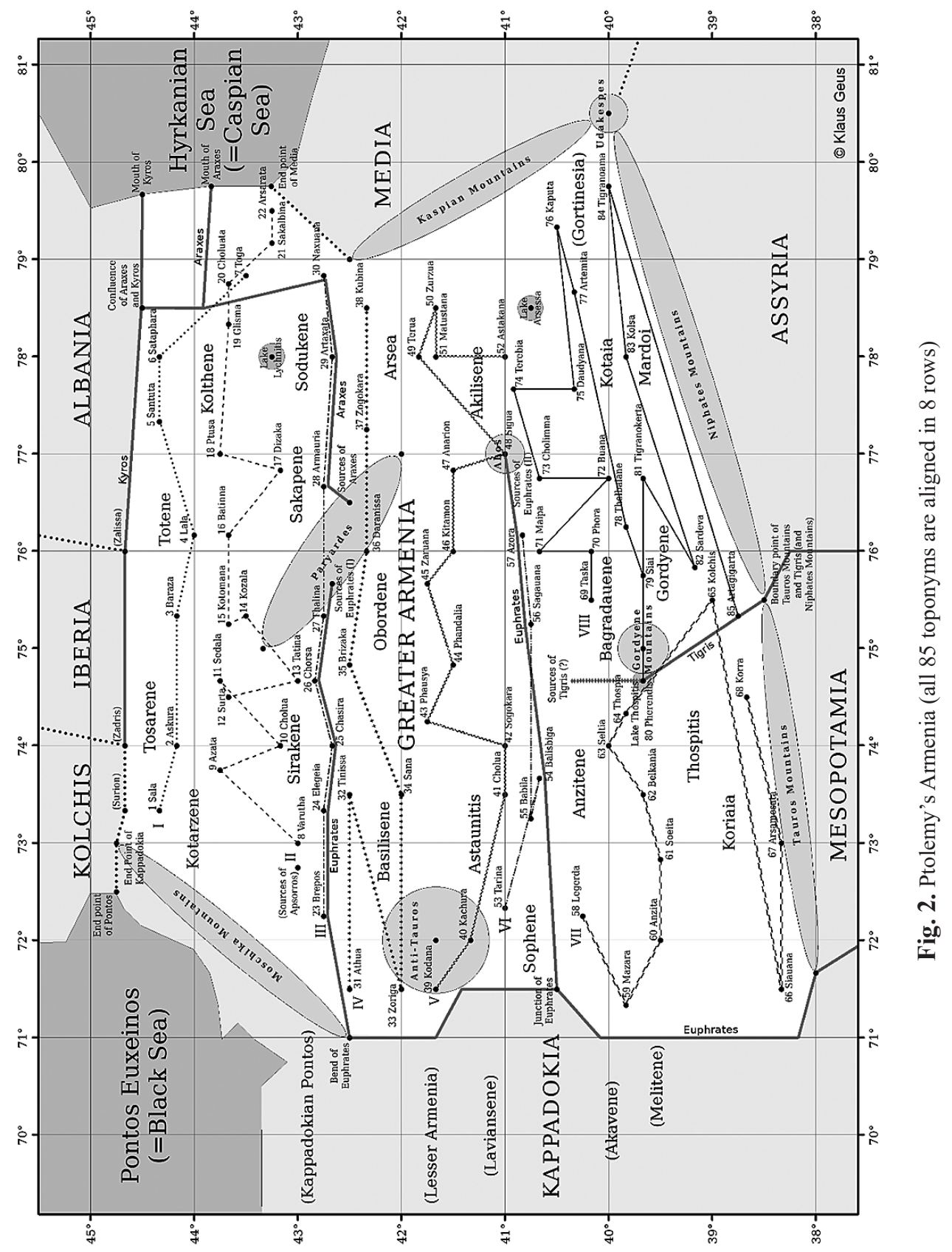


At first sight (see Fig. 2) these rows look like routes, streets or waterways, which a traveler would take when travelling in an east-west-direction, but a closer look shows some strange inconsistencies. For example: why do rows 1 and 2 intersect in the East near Choluata (20)? why does row 6 stop at Azora (57)? Or, probably the strangest feature of Ptolemy's map: why is the southernmost segment split into two rows, one in the southwest, one in the southeast, but both, after running in an eastern direction, make a turn to the west?

Such inconsistencies prompted Hewsen to hypothesize that Ptolemy, when reading the toponyms off of one or more maps, made several mistakes.

Indeed, if this was the case, Ptolemy's map of Armenia would be, in Hewsen's words, a "parody of his earlier work ... and method." Interdum dormitat Homerus, but thinking that a scientist of Ptolemy's caliber committed such a number of gross errors is absurd. Furthermore, Hewsen's hypothesis does not solve all puzzles. Any sane mapmaker would for example have read off the toponyms in rows 7 and 8 all at once without making any turns against the general direction as in the previous rows. There is clearly something suspect here. In the following I shall advance an alternative hypothesis in order to explain Ptolemy's ‘many' errors.

\section{What is Wrong with Ptolemy's Coordinates? The status quaestionis}

Ptolemy's Geography consists mainly of a huge catalogue of more than 8,000 toponyms and more than 6,000 pairs of coordinates. ${ }^{5}$ When plotting them onto a map one will notice many mistakes, most prominently an 'overextension' of the oikumene in the eastwest-direction (see Fig. 3, 4, and 5). ${ }^{6}$

Modern scholars have tried to explain these inconsistencies by a barrage of different, sometimes competing and conflicting arguments, e.g., errors in measuring distances, different units of measurements or different lengths of the Greek stade, scribal errors, wrongly adjusted regional maps etc. ${ }^{7}$ For sure, such errors can happen (and probably did happen) but this does not suffice to explain, i.a., the overextension of Ptolemy's world map. Why should errors in measurements on the ground occur over the whole oikumene predominantly in an east-west direction? Or why do we encounter certain types of errors on a regular basis, e.g. 'doublets' of the same toponym and 'inversions' or 'switches' in

4 Cf. Licini 2017, 79: "From the description I can conclude that Ptolemy's map of the Caucasus is as distorted as that of Britain. At the very best, distorted as it is, the course of the Euphrates River, currently. Firat Nehri, is an utter confusion of names at pleasure, a conjectural location of nonsense within geographical coordinates of 'nowhere' that could have deceived even Traian's commanders in A. D. 114." Despite the fact that Licini notices the distortions and even makes the comparison with Ptolemy's Britain, she falls short of explaining these errors. Who would entertain the idea that a sober mind like Ptolemy invented names at pleasure or conjectured coordinates?

5 On the question of the transmission and tradition of Ptolemy's maps, see Mittenhuber 2009 and Mittenhuber 2010.

6 The landmass between the Black Sea and the Caspian Sea amounts to ca. $8^{\circ}$ (instead of $6^{\circ}$ ). Hewsen's (1990) atlas on ancient Armenia is very useful for comparing ancient and modern topographical data.

7 The manuscripts of Ptolemy's Geography are comprehensively described in Burri 2013. 


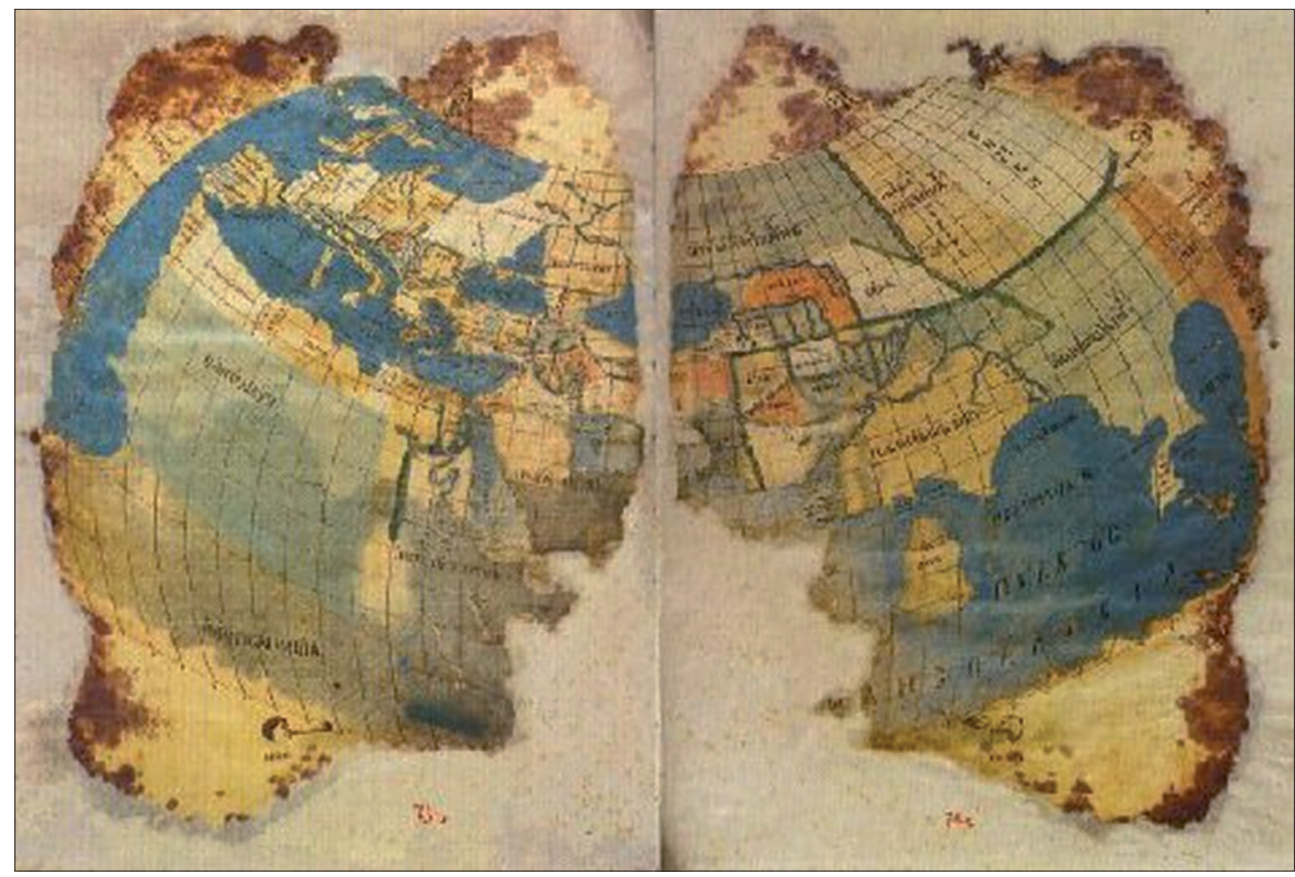

Fig. 3. Codex Constantinopolitanus Seragliensis, Istanbul (13th cent.)

(Note the overextension of the oikoumene in the east-west direction!)

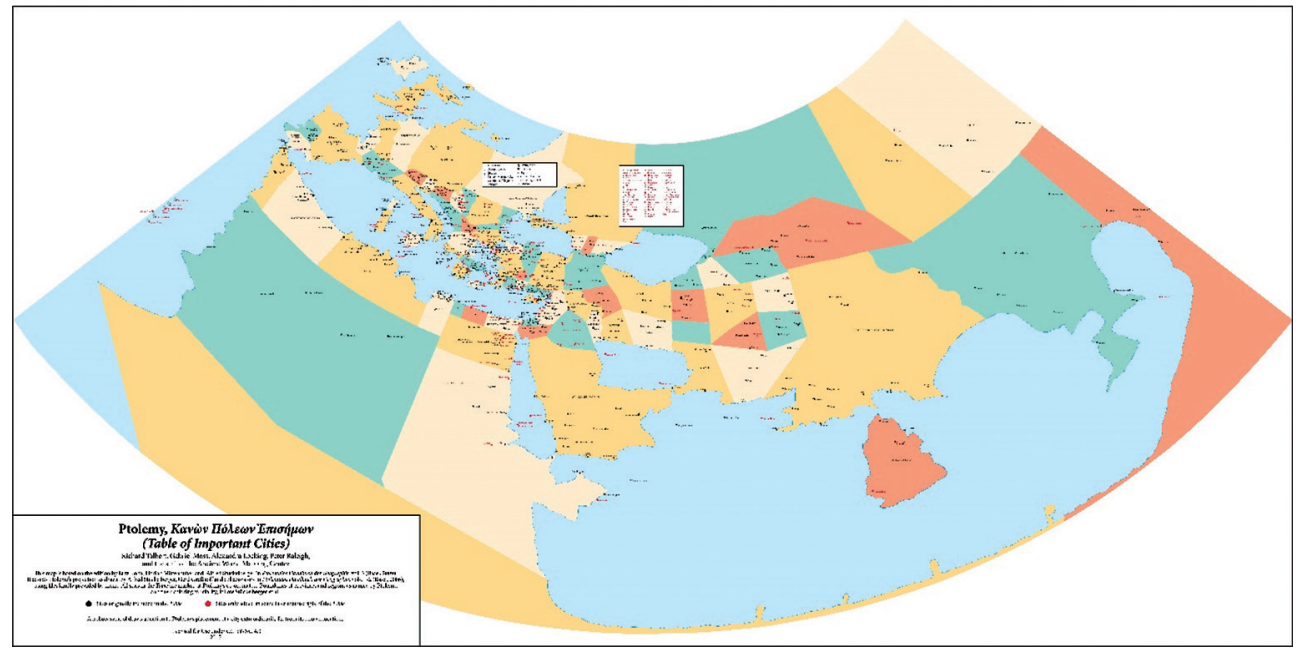

Fig. 4. Ptolemy's world map ("Table of important cities," as realised by AWMC 2017 (the oikumene is 'stretched', especially in Asia, from ca. $120^{\circ}$ to ca. $\left.180^{\circ}\right)$ ) 


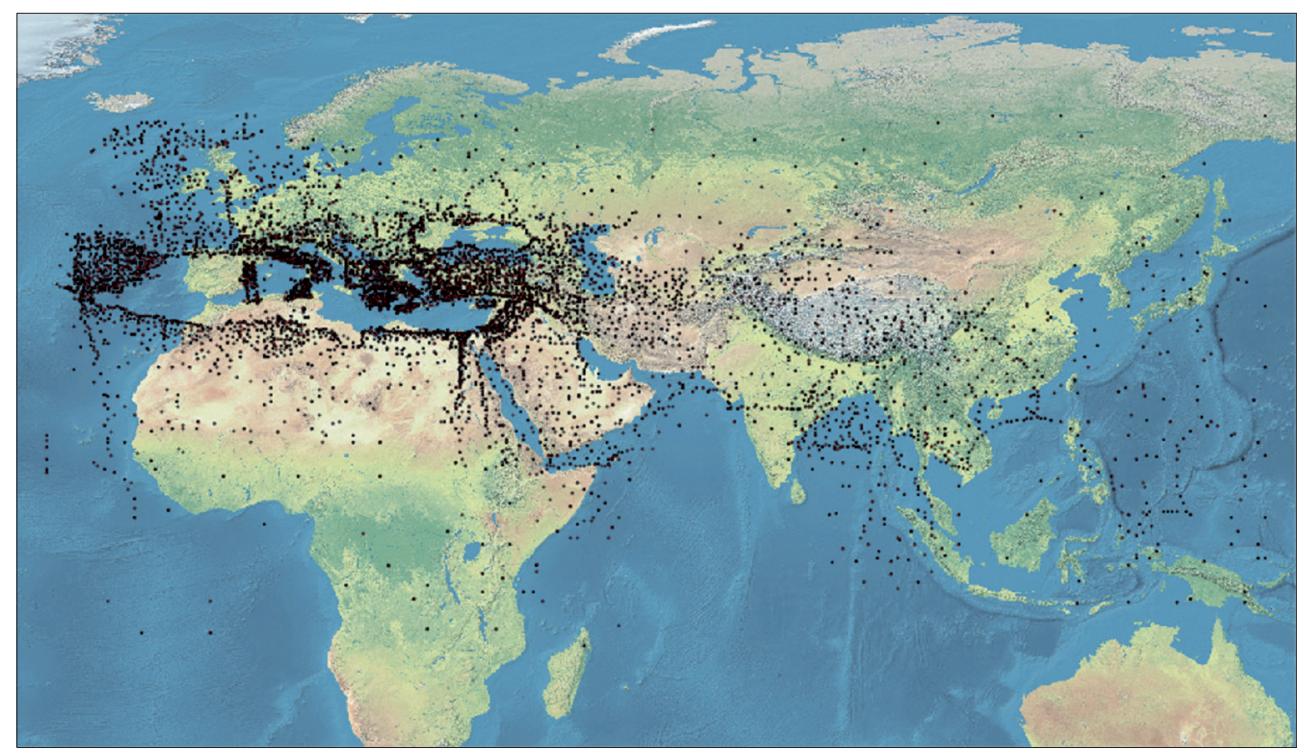

Fig. 5. The oikoumene according to Ptolemy (all Ptolemaic locations are mapped onto a modern world map)

the sequence of places along routes or coastlines? In sum: how could a true genius like Ptolemy have made so 'many mistakes' in the field of cartography?

A few years ago astronomer and historian of science Irina Tupikova came up with the idea that the vast majority of all these seemingly different errors boils down to only one, namely that Ptolemy, while converting terrestrial distances into spherical coordinates, used the wrong circumference of the Earth. ${ }^{8}$

Indeed, Ptolemy himself pointed out in his introduction that he subscribed to the (Posidonian) value of 180,000 stades instead of the more correct (Eratosthenic) value of 252,000 stades.

While the length of the Greek stade may be debated, it is nevertheless clear that the Posidonian value is too small: even with a length of a stade of $185 \mathrm{~m}$, we would arrive only at $33,300 \mathrm{~km}$ for the circumference of the earth $(180,000 \times 0,185 \mathrm{~km})$, whereas the actual value is about 40,000 km. Hence, Ptolemy's circumference of the Earth is too small in any case. Modern scholars tend to neglect the importance of this factor, thinking that 'blowing up' a 'smaller' sphere to a 'bigger' sphere would not change the so-called central angles and, therefore, the spherical coordinates at all. This is, however, wrong. This would only be true if Ptolemy had made astronomical observations at every single location. But, as he himself stated in his introduction, he calculated the spherical coordinates from terrestrial distances. In such a process, the adopted circumference of the Earth is of crucial importance.

8 Tupikova 2013; Geus - Tupikova 2013a; Tupikova - Schemmel - Geus 2014. The mathematical formulae for recalculating Ptolemy's coordinates are published in Tupikova 2014. 
To make this point clear: Let us assume that the actual size of the earth is, as Eratosthenes claimed, 252,000 stades. Ptolemy calculated $1^{\circ}$ as 500 stades (being equivalent to $180,000: 360)$. But for Eratosthenes $1^{\circ}$ equals 700 stades $(252,000: 360)$. This means that a terrestrial distance of, e.g., 700 stades would be represented as $1^{\circ}$ in longitude or latitude on the 'Eratosthenic' map and as $700: 500=1.4^{\circ}$ on the 'Ptolemaic' map. In other words, every distance, measured in stades, is represented by Ptolemy on the surface of the earth with an arc of the great circle which is bigger than it should be by a factor of 1.4 (a difference of $40 \%$ !).

This basic idea has the ability to explain the 'overextension', the 'stretch' of the Ptolemaic oikumene along the east-west direction. Since Ptolemy adhered, as far as possible, to transmitted astronomical data, especially to the latitudes of important cities, he adjusted the distances expressed in bigger angular measure ('degrees') to the known latitudinal circles of these cities. As the transmitted distances were correct, he needed to place them farther to the east or to the west than their actual positions.

As this hypothesis lies at the heart of our mathematical approach of recalculating Ptolemy's coordinates, I try to bring home his point with a modern simile. What Ptolemy has basically done, was to 'press' accurate distances into an Earth too small. In addition, he used astronomical measurements, e.g., the latitudes of some important cities like Rome, Alexandria or Byzantium. One may imagine an American 'burger' consisting of several layers of ham, cheese, lettuce leaf, and ketchup. If you press the burger, the layers remain basically intact and in the same place, but the 'ketchup' is moving to each side of the burger. The same happened in Ptolemy's process. Locations 'glide' to the west and east, while the north-south positioning, fixed by the astronomically determined latitudes of important cities, remains for its most part unchanged.

As will be obvious by now, the implications of adopting the wrong circumference of the Earth, while calculating terrestrial distances into spherical coordinates, are enormous.

The main consequences may be summarized as follows:

1. Ptolemy's map expands not in relation to one single point (lying on his prime meridian, the 'Islands of the Blest', the 'Canaries', in the Far West), but in relation to every point which he used to adjust known distances, i.e. to different reference points, referred to by Ptolemy as themelioi, 'cornerstones'.

2. Each recalculation of the Ptolemaic coordinates to a sphere of another (e. g. the modern) size can, in principle, be performed only locally, i.e. relative to a chosen reference point. ${ }^{10}$

3. There cannot be one single 'reconstructed' Ptolemaic map. Rather, the Ptolemaic world map consists of 'sets' or 'families' of different local 'maps', each one linked to one specific reference point.

4. Modern statistical approaches to recalculating Ptolemy's coordinates are doomed to fail, as the 'deviation factor' between ancient and modern positions is not fixed and can vary (quite) considerable.

9 The position of the modern 'zero point' for counting longitudes, the 'Greenwich Meridian', cannot be defined unambiguously in Ptolemy's system of coordinates.

10 Every comparison of the Ptolemaic coordinates with their counterparts on modern maps must indicate which reference point was used to link both the Ptolemaic and modern coordinate systems. 
Yet other consequences of Ptolemy's mapping of distances onto a smaller Earth manifest themselves on a local level, i.a. 'doublets' of locations, ${ }^{11}$ 'switching' and 'rotating' of regions, and 'inversion' of locations in the ordering (e. g. along a road or coastline).

At this point one may ask: what have 'doubles' to do with the wrong circumference of the Earth? The following diagram (Fig. 6) tries to elucidate this problem:

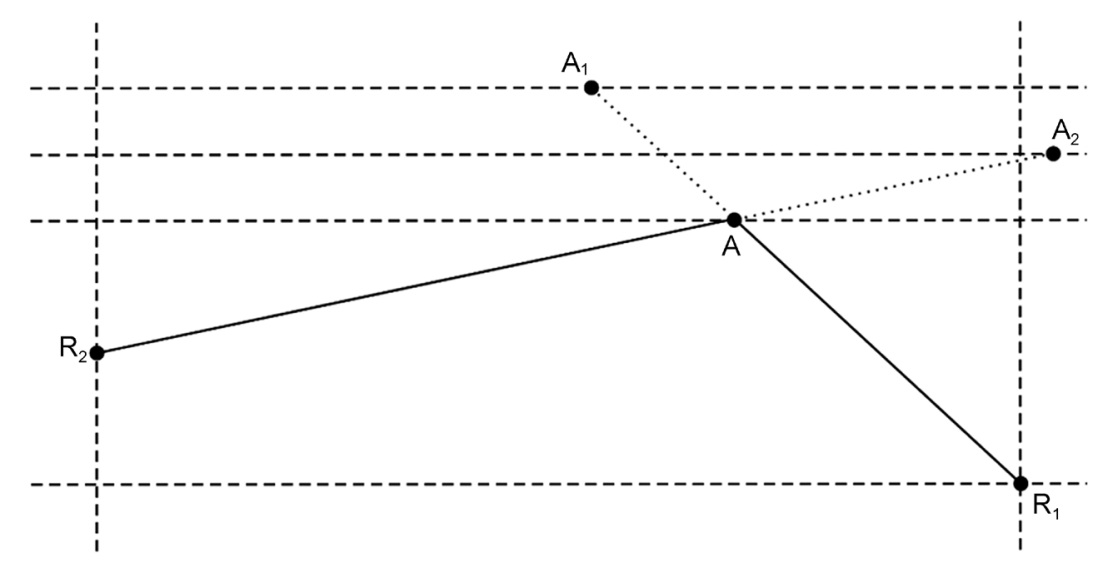

Fig. 6. 'Doubling' of location A in Ptolemy's mapping when measured from two different reference points $R_{1}$ and $R_{2}$

Two distances towards a point A, which was not recognized as one and the same location, were known in relation to two different reference points $R_{1}$ and $R_{2}$, e.g., from two different travel reports (periploi or itineraria). On Ptolemy's map, based on a smaller circumference of the Earth, the (correct) distances are consequently mapped 'longer', i.e. further out in the original direction. Point $\mathrm{B}$ is appearing twice as $\mathrm{A}_{1}$ and $\mathrm{A}_{2}$ on Ptolemy's map. ${ }^{12}$

A similar effect, which we call 'inversion', happens when a sequence of locations is mapped from two different reference points.

The distances towards the points a and B were known in relation to the different reference points $R_{2}$ and $R_{1}$, respectively. On Ptolemy's map, the points a and B are mapped in the same direction at longer distances (dashed lines), at $\mathrm{A}_{1}$ and $\mathrm{B}_{1}$, respectively. The positions of a and B seem to be 'inverted'.

11 Sometimes even whole regions, mountains or rivers are doubled (see, e.g., Tupikova - Schemmel Geus 2014 for the mountain and river system in the Ptolemaic Far East, a feature which was intuitively recognised by de La Vaissière 2009); clearly the second branch of the Euphrates river in Ptol. geogr. 5.13. 5 is a doublet of 5.13.12. By extension of that, the mountains Abos (where the 'second' Euphrates river originates) and the Paryardes (where the first Euphrates river originates) should be identical or parts of one another.

12 This happens quite often in the same region. 


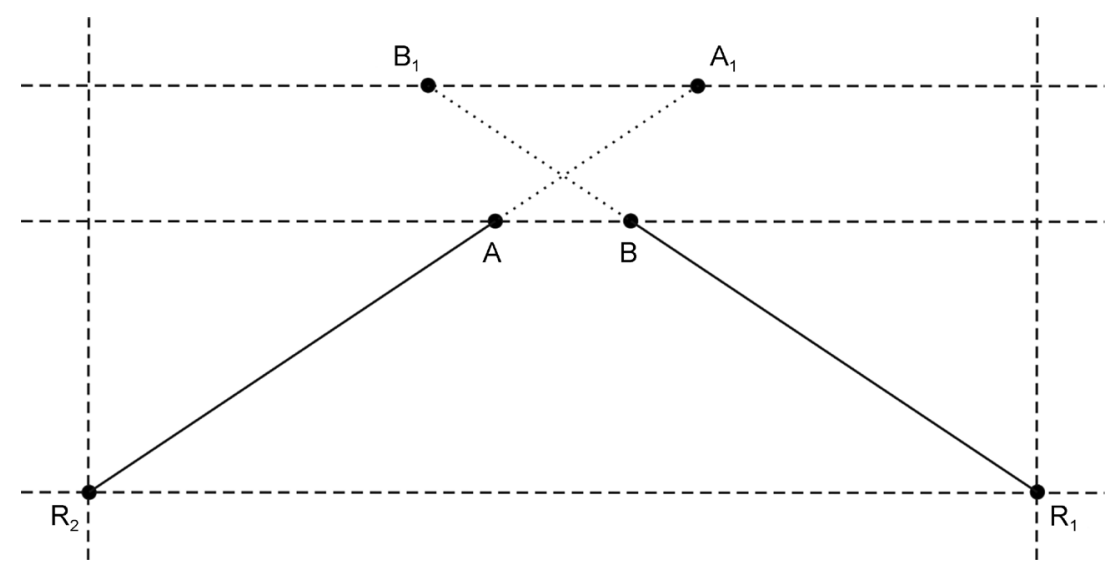

Fig. 7. 'Inversion' of locations in Ptolemy's mapping

These phenomena are likewise direct consequences of the same basic error, the wrong circumference of the Earth. Admittedly, the thousands of terrestrial distances Ptolemy found in his sources are measured from different reference points, e. g., from major cities like Rome, Alexandria, Byzantium, but also from neighbouring cities etc. Since every reference point already has its own individual distortion on the Ptolemaic map, all modern attempts to recalculate Ptolemy's coordinates with only one 'deviation factor' of 1.4 are doomed to fail. ${ }^{13}$

The only way to cut the Gordian knot is first and foremost to detect the reference point of every location in question and, second, adjust the respective points linked to this reference point. Only then will it be possible to recalculate the original distances Ptolemy had at his disposal, and, finally, the correct coordinates by applying mathematical formulae of spherical trigonometry. This is easier said than done. Ptolemy's geographical data were far from being uniform. Sometimes the direction in which a city lies in relation to another city was stated in his sources, sometimes not; sometimes the latitude at which a certain place lies was stated, sometimes not, sometimes only the distances to one location were known (a common case when Ptolemy simply used the intersection points of a pair of compasses), sometimes not, etc. In other words: one has to distinguish between different case scenarios and hence employ different mathematical formulae and procedures. ${ }^{14}$

I will now come to historical geography proper, more precisely, to Ptolemy's Armenia.

13 See Tupikova - Geus, forthcoming.

14 The preliminary results of our recalculation have confirmed our assumption that the original distances were given on a sphere the circumference of which approximately equals 250,000 units ('stades') and transferred by Ptolemy to a sphere with the circumference of 180,000 units. Although our recalculations do not presuppose any metrical value of the Greek stade, the striking match of our recalculated coordinates with their actual counterparts hints to Eratosthenes' estimation of the Earth's circumference as being very accurate. As a result, the estimation of the 'Eratosthenic' stade as $157.5 \mathrm{~m}$ seems very reasonable. This result is also confirmed by recent statistical investigations carried out by other scholars. Finally, it is also confirmed by what I have discussed in the previous chapter, i.e. that the Greeks used mainly an 'itinerary stade' of 150-160 metres for regional distances. 


\section{What Needs to Be Done with Ptolemy's Coordinates?}

As should be obvious by now, I very much disagree with Hewsen's assessment of Ptolemy's map of Greater Armenia rivalling the worst part of his Geography and being a 'parody' of his work. In fact, I claim that Ptolemy, or rather his sources, were very wellinformed about Armenia, probably even more than about most other regions outside the Roman Empire. Ptolemy simply committed one single but crucial error causing the apparent 'chaos' on a local level. ${ }^{15}$

Ptolemy clearly did not rely on one single reference point, and by extension, on one single source/'Vorlage', e.g., an itinerarium, a description or a map of Armenia, but on several different accounts. Up to now we have tentatively identified several possible reference points for Armenian cities. ${ }^{16}$ By "tentatively" and "possible" I mean that we have found cities which are attested as historical landmarks or starting points as well as points, which provide, after our recalculation, accurate or at least reliable distance specifications.

The following illustration indicates some possible reference points for one example, Artaxata.

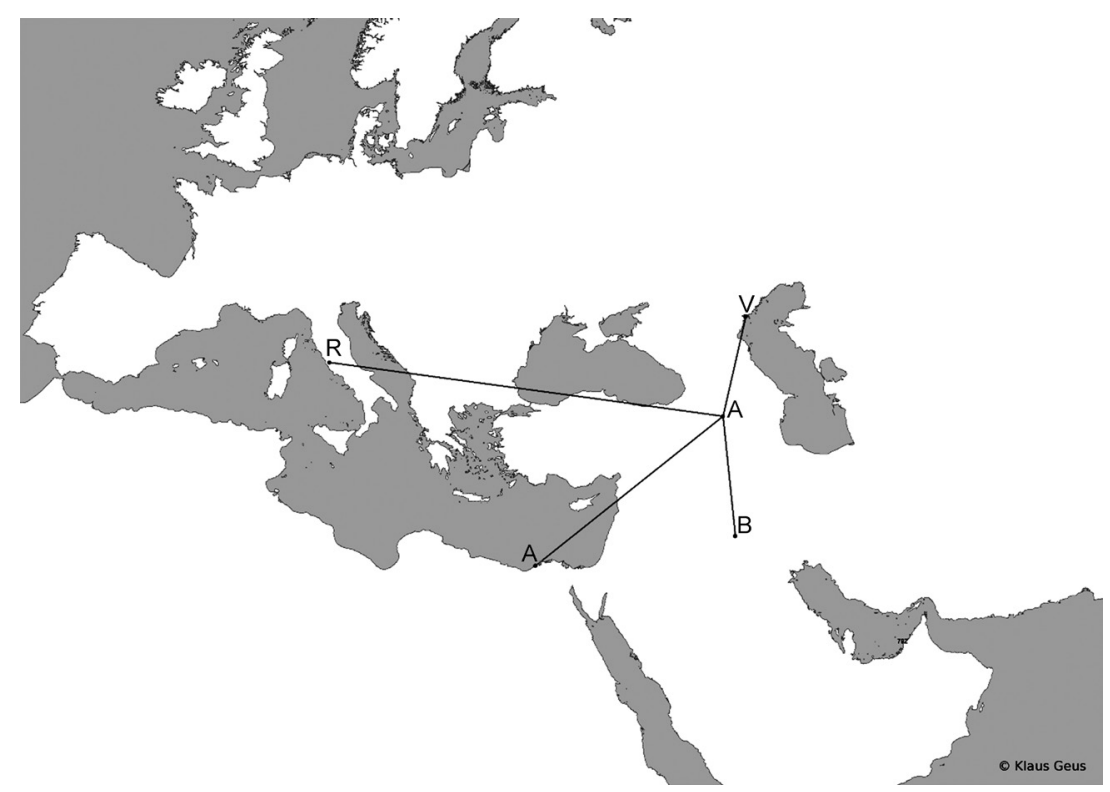

Fig. 8. Possible reference points for Artaxata (Rome; Alexandria; Babylonia; Mouth of Volga river)

15 While I agree with some of his observations and assumptions the overall idea of Mouraviev 1992 is simply wrong. The strange image of the Caspian Sea on Ptolemy's map has nothing to do with hydrographical but with spherical data and problems.

${ }_{16}$ My project on Ptolemy's Armenia is still work 'in progress' due to a variety of reasons. Among them is the study of the complex mixture of sources to which Ptolemy, or rather his main source, Marinus of Tyre, had access to. In contrast to other regions, these sources used different units of measurements, i.e. Greek stades and Roman miles (or rather Roman miles calculated as 8 or $81 / 3$ stadia). 
Up to now, the recalculations make the following four reference points plausible: Rome; Alexandria; Babylonia; Mouth of Volga river.

Hardly surprising, Rome as the center of the Roman Empire is a common reference point for other regions as well. Furthermore, we know that the Emperor Trajan took Rome as the starting point for his campaign against the Parthians in the autumn of AD $113 .{ }^{17}$

Equally unsurprising, Alexandria is a common reference point for Ptolemy as well. We may speculate that measurements in connection with Alexandria point to Mark Antony's campaign in $34 \mathrm{BC}$ which included a return to Alexandria. But this is mere speculation.

The third reference point which yields extremely good measurements is the mouth of the river Rha, the Volga. The reason for this is hard to explain: As I am not aware of an expedition touching both the Volga river and the region Armenia, it may simply mean that the mouth of the river Rha was well-known to other reference points like Rome and Alexandria, meaning that all the reference points belong to the same 'family' or 'set' of regional maps. ${ }^{18}$

The fourth reference point is Babylon. Interestingly, good results are not obtained by the 'long' stade of $185 \mathrm{~m}$, i.e. a measurement carried out by the Romans, but by a short, or more precisely, 'itinerary' stade of 157,5 . This hints at a Greek source, possibly even at one from the time of Alexander the Great when the bematists measured most of the former Achaemenid Empire.

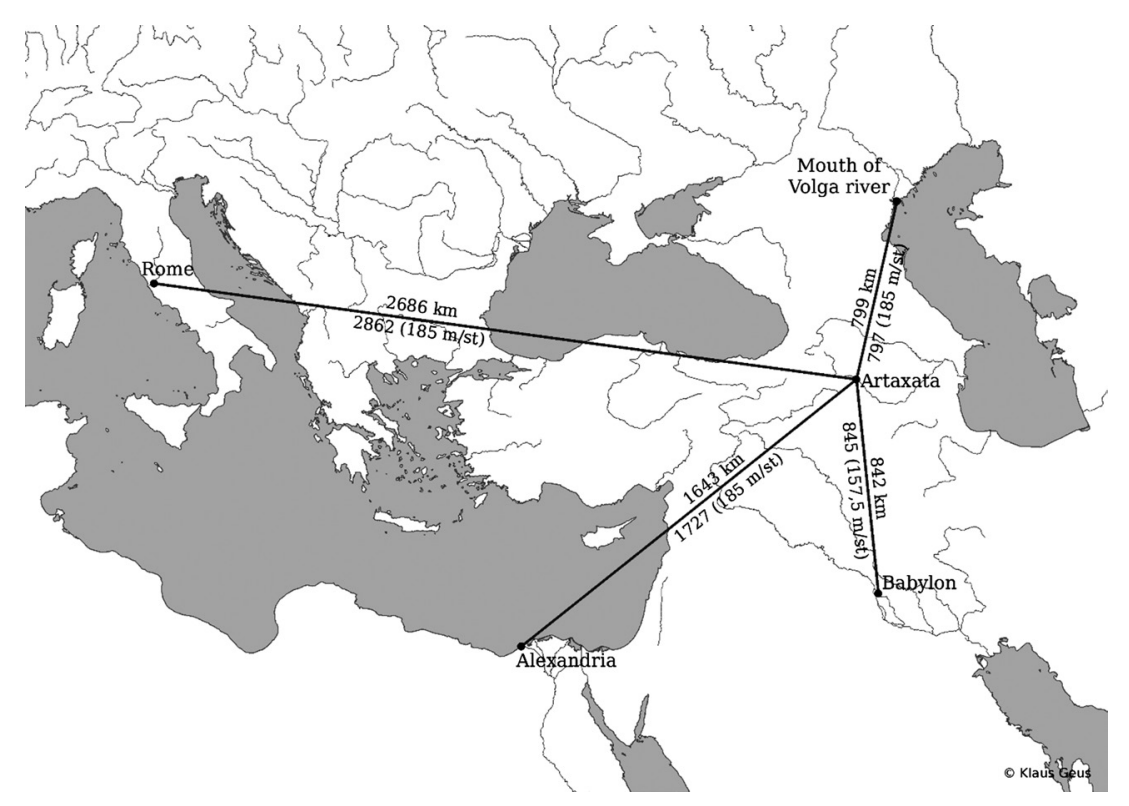

Fig. 9. Real and recalculated distances for possible reference points of Artaxata: Rome, Alexandria, Babylon, and Mouth of Volga river

17 See, e.g., Bertinelli 2000; Strobel 2019.

18 Cf. also the example of Kars/Cholua discussed infra. 
Our preliminary results have been checked with other cities in Ptolemy's catalogue of Armenian toponyms:

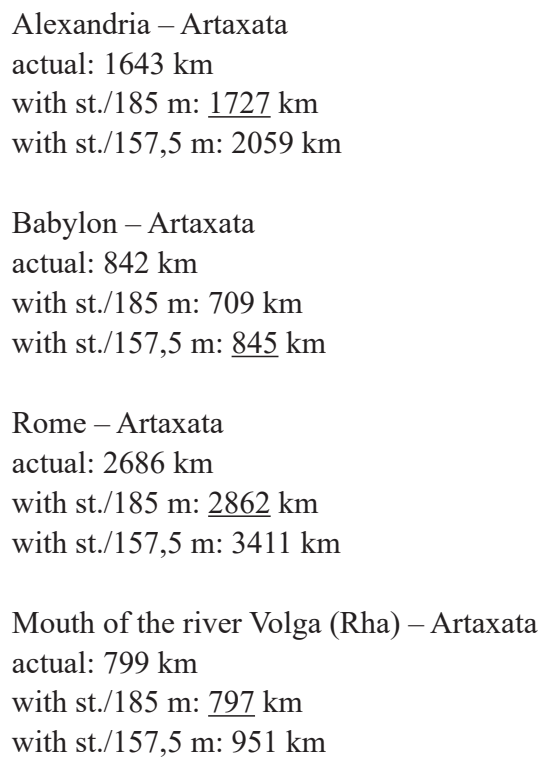

The results of our recalculations point to two different lengths of the Greek stade ("st.") in Armenia, which leads me to my final point.

\section{Some Preliminary Findings}

Another proof for the viability of our hypothesis of several reference points is the existence of doublets in Armenia. Already Hewsen wondered whether Chasira (no. 25) and Chorsa (no. 26) are one and the same city. ${ }^{19}$ Indeed they are, and we are now able to explain the reason for it. The city in question is modern Kars in Turkey, near the border to Armenia. ${ }^{20}$ This important city was measured (at least) twice in antiquity: on the one hand from the west, probably from Rome via Elegeia, modern Erzerum, on the route to Armavir; but it was also measured from the south or south-west, either from Alexandria or from Babylon via the river route on the Euphrates. ${ }^{21}$ While compiling his catalogue of Armenian cities Ptolemy did not realize that the names of Chasira and Chorsa, which he found in two separate sources or sections, referred to the same city. Hence, after converting the terrestrial distances Kars popped up twice on Ptolemy's map. As there is another unexplained toponym with a similar name in the vicinity-Cholua ${ }^{22}$ - one may argue

19 Hewsen 1982, 125.

20 At a latitude of $40^{\circ} 36^{\prime} \mathrm{N}$.

21 For the short itinerary of the emperor Traian in Eutr. 8.3 and the toponyms mentioned there, see Licini 2017, 105-119.

22 Cholua itself is mentioned twice (!) in Ptolemy's Geography (5.13.11 u. 5.13.14) as nos. 11 and 41. 
that Kars was even 'measured' a third time, probably again from the river route on the Euphrates but linked by Ptolemy with a different set or 'family' of toponyms, thus causing not only a 'third' Kars but also the strange second 'branch' of the Euphrates river on this map of Armenia (cf. Fig. 10).

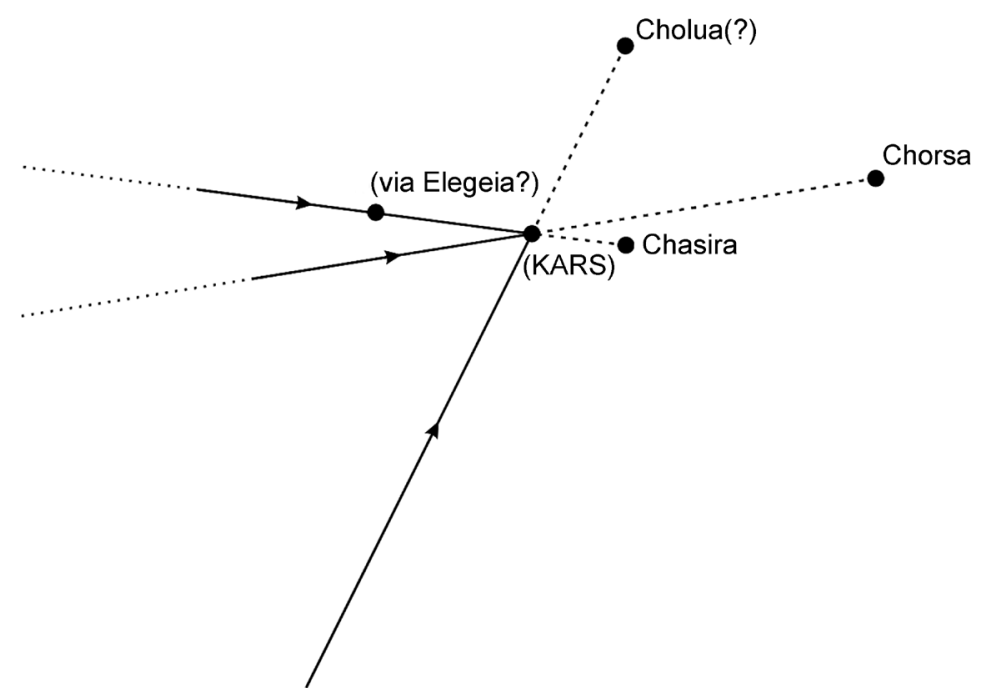

Fig. 10. A possible doublet (or triplet?) of Kars in Armenia: Chasira (25), Chorsa (26) (and Cholua (10)?)

To make things even more interesting we may also speculate whether a mysterious second Cholua (41) is to be explained along the same lines, i.e. as a quadruplet of Kars. ${ }^{23}$ Even a city of similar name, Choluata (20), far off in the northeast of Greater Armenia is not completely out of question, as it lies in the same direction as Chorsa (cf. Fig. 11). ${ }^{24}$ This identification does, however, require further research (see 5: Conclusion and Outlook).

There are several 'candidates' for doublets in Ptolemy's chapter on Armenia and adjacent provinces ${ }^{25}$, either regions (e.g., Koriaia/Kotaia; Gordyene/Gortinesia; Basilsene/ Akilsine) or cities (e.g., Phora/Pherendis; Arsarat/Artaxata; Brizaka/Brepos). The identification of - probably quite a lot of - doubles (which may be found on all fringes of the oikumene $)^{26}$ will significantly reduce the number of Armenian toponyms in the long run.

In addition, understanding Ptolemy's method and the consequences of his basic error will also lead to a better understanding of the received text. I shall discuss a final example.

23 As shown above, a reference point in the Far North, probably to be identified or connected with the mouth of the Volga river, is likely.

24 Note that rows 1 and 2 intersect at Choluata (20) which signals a change in the sources.

25 See, e.g., Daskusa (5.7.2) and Dagusa (5.7.5), or Sismara and Zimara (5.7.2), all of them lying at the Euphrates river in Lesser Armenia.

26 For the North, see Geus - Tupikova 2013b; for the East: Tupikova - Schemmel - Geus 2014. 


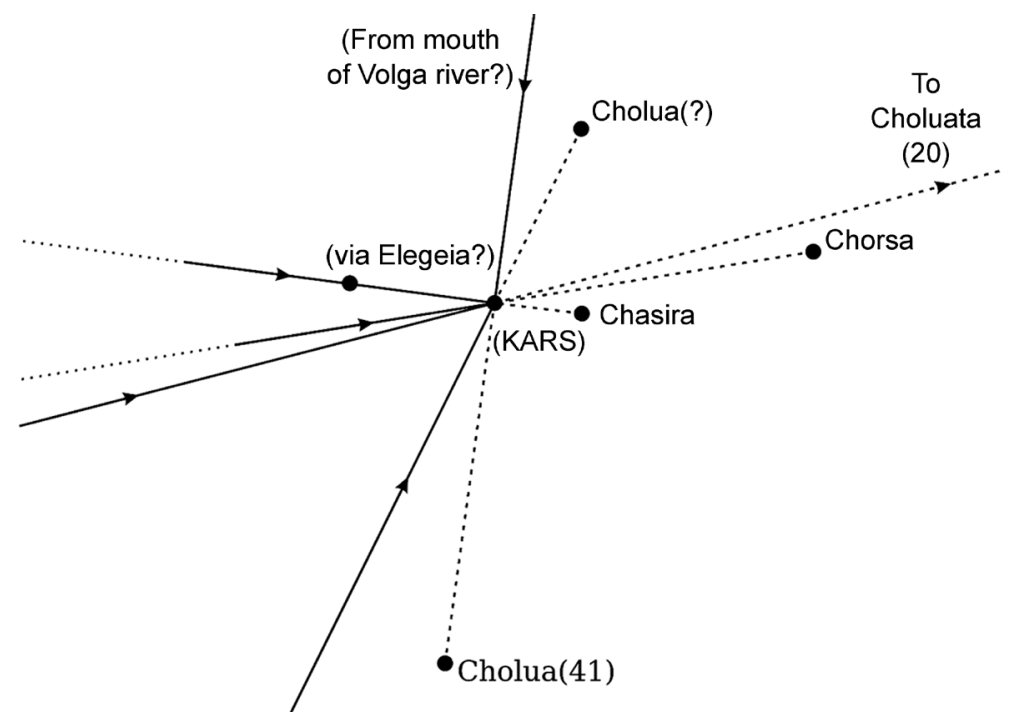

Fig. 11. A possible quadruplet (or quintuplet?) of Kars in Armenia: Chasira (25), Chorsa (26), Cholua (11), Cholua (41) (and Choluata (20)?)

The upper part of the Tigris, as described in Ptolemy's text (5.13.7), makes little sense to me:

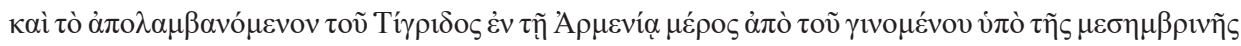

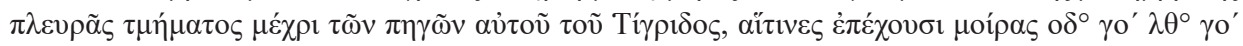

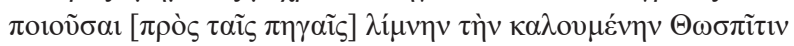

and the part of the Tigris river, which is in Armenia, (flows) from the section below the southern 'flank' toward the sources of the Tigris river itself, which have (the coordinates) $74^{\circ} 40^{\prime} / 39^{\circ} 40^{\prime}$, creating at the sources the sea called Thospitis.

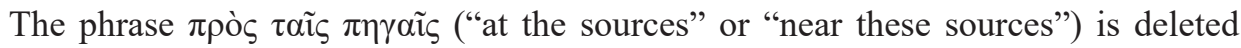
by all editors following Wilberg's 1845 example. But this does not solve the problem at all, as the Tigris river is still flowing backwards "to" (mechri) its own sources. The overall sense can only be that the Tigris river originates in the north (but to the south of the previously mentioned Euphrates river) and flows from there to the south, first to the Lake Thospitis and then to the border of Assyria - thus creating an image of a river/ lake system similar to the Nile river and the Nile lakes in Ethiopia. ${ }^{27}$ Most likely, a set of coordinates for the sources of the Tigris river was lost during the process of transmission prompting a medieval scribe to try to emend this mess. ${ }^{28}$ But there is a second problem in this sentence. According to 5.13.22, the city of Pherendis lies at $74^{\circ} 40^{\prime}$ ' $39^{\circ} 40^{\prime}$ - exactly the same coordinates as the sources of the Tigris river and Lake Thospitis. Surely, no Armenian city was ever built in the middle of a lake! This problem is

27 Cf. 4.7.24. 26. 31; 4.8.3.

28 I have tried to highlight this problem by drawing a wiggly line in the north of the Lake Thospitis. 
to be associated with the generation of doublets as explained above. The final section of Ptolemy's Armenian chapter (5.12.22) after the dubious line "and beneath/in the south of that (i.e. the section mentioned in 5.12.21) is the Gordinesia" ${ }^{29}$ clearly mirrors some elements of the previous sections, e.g., Gordyene $=$ Gordinesia or Phora $=$ Pherendis. As shown above, even 'multiplets' are possible. Hence, we may speculate that some cities pop up more than two times, as modern Silvan is probably identical with Siai (or Sitae in the Tabula Peutingeriana), Maipa (aram. Mîyâfâriqîn, Maipherqat, Maiferkat), ${ }^{30}$ Tigranocerta and Tigranoama. The whole eighth row in the southeast, strangely separated from the seventh row in the southwest of the Armenia map in Ptolemy's Geography, is nothing more than a duplication of the other.

One may find it puzzling that Ptolemy did not notice such doublets. This may be explained mainly by two facts: firstly, the source material Ptolemy used (via Marinus) was not uniform in terms of organization, language, and time. In this regard, it differs vastly from other geographical works in antiquity. As I have tried to show elsewhere, ${ }^{31}$ the huge amount of more than 8000 toponyms derives from the archive of the central administration of the Roman Empire. In other words, Ptolemy used primarily documentary, not literary sources, e.g., lists of cities, itineraria, travelogues etc. from different times. Hence, uniform spelling of toponyms, renaming of cities and regions, an identical frame of reference or topographical ordering of the locations, the same unit of measurements etc. cannot be expected. Furthermore, Ptolemy took no interest in geographical matters per se. He was first and foremost an astronomer who worked in the field of geography for only a short period of his life and relied heavily on a single geographical source, Marinus (ignoring all other geographers like Eratosthenes, Strabo etc.). Ptolemy was, however, intent on presenting geographical data in a completely new way: in the form of spherical coordinates. Ptolemy demonstrated the usefulness of his idea by writing an inspirational "Introduction to Geography," compiling huge and comprehensive lists of toponyms of the whole oikumene with coordinates (calculated from terrestrial distances found in Marinus' earlier works) and drafting a world map and 26 regional maps. One may call Ptolemy a 'geographer' because of his profound contribution to the field of geography, but he was, as mentioned, more of an astronomer, mathematician and cartographer. Dabbling with geographical or rather chorographical minutiae was not his main concern. ${ }^{32}$

\section{Conclusion and Outlook}

The geographical information on toponyms and locations in Armenia at Ptolemy's disposal was exceptional — not only in terms of quantity but also in quality. The terrestrial distances between the locations were measured (or rather counted) accurately in Greek

29 This line, missing in the UKX tradition, but present in the VR manuscripts, was deleted by Müller 1901, 949. and put in parenthesis in the Bern edition (Stückelberger - Graßhoff 2006).

30 Cf. the Bern edition (Stückelberger - Graßhoff 2006), 555, note 214.

31 Geus 2017b.

32 Ptolemy made this clear in his introduction (1.1), when he discussed the difference between geography and chorography and claimed that the geographer had to look at the 'whole' picture, concern himself only with 'important parts' and leave the 'details' ( $\mu 1 \kappa \rho о \mu \varepsilon \rho \varepsilon ́ \sigma \tau \varepsilon \rho \alpha)$ to the chorographer. 
and Roman times. ${ }^{33}$ Ptolemy, however, made, while converting the distances into coordinates, one fundamental mistake: calculating the latitudes and longitudes for a smaller circumference of the Earth's globe, all these accurate distances received a shift mainly in the east-west direction..$^{34}$ In addition, every location also has an individual aberration factor, depending on the reference point, i.e. the point from which the distances to the locations were measured. This single but crucial mistake is responsible for the entire 'chaos' observable on the local level, e.g., the misplacement of cities ${ }^{35}$ and regions or the generation of doublets.

With the help of mathematical formulae of spherical trigonometry, one may recalculate Ptolemy's coordinates for each position, provided that the correct reference point in question is identified.

Our preliminary findings for Ptolemy's Armenia show that Ptolemy used several reference points, among them, as expected, Rome, Alexandria, and Babylon. This points to different sources, i.e. different itineraria or travelogues (or regional maps). Interestingly, these itineraria seem to come from different times and 'cultures', as we find distances measured in the so-called 'itinerary stade' of $157,5 \mathrm{~m}$ (used by Greeks) and in the longer stade of $185 \mathrm{~m}$ (the latter simply a recalculation of the Roman mile according to the usual ratio $1: 8$ ) in Ptolemy. In other words: Ptolemy's Armenia is clearly not based on one single source. Rather, it is a mélange of different, but reliable accounts of the region. Further research on Armenian toponyms has to take these findings into account.

How does one proceed from here? I shall close my paper with some caveats on the use of Ptolemy's place-names.

As the deviation factor varies greatly in Armenia it is futile to look at the Ptolemaic map when identifying Armenian place-names. The coordinates of ancient sites may be correct in one instance but may differ dozens, if not hundreds of kilometres in the other. Examples in other chapters of Ptolemy's Geography, where cities have been 'shifted' even to other regions and provinces may be mentioned. ${ }^{36}$

Toponyms, therefore, should first be evaluated on linguistic or toponomastic grounds. As Ptolemy was probably drawing heavily on documentary sources, e.g., unpublished

33 On the accuracy of ancient measurement data, see Geus, Tupikova 2019. For a different view Shcheglov 2016; Shcheglov 2018 who thinks in terms of 'overestimation' and 'underestimation' of distances and different values of the Greek stade in order to explain all (!) distortions of Ptolemy's maps. Neither was "estimation" involved in most 'measuring' processes of ancient distances nor did the question of different stadia play a major role. Ancient bematists and surveyors simply counted their steps. Within a net of connected locations, smaller errors in distances (e.g., by deviations or shorter steps due the terrain) cancel themselves out. See Tupikova - Geus, forthcoming.

${ }^{34}$ As explained above, there should have been a shift in the north-south-direction as well, but as Ptolemy used some astronomical measurements of latitudes the shift is noticeable only in regions where he had no such data available. This seems to be the case for Greater Armenia, where some cities were 'pushed' more than $2^{\circ}$ to the north. Cf. Winkler - Mittenhuber 2009, 293.

35 The misplacement of locations (and sometimes of peoples as well, as they are often associated with important cities) can add up to dozens, if not hundreds of kilometres. See, e.g., Licini 2017, 90 (after a lengthy discussion on the identification of the Alabanos river in 5.12.1): "The Alazani are misplaced on the map by several hundred miles eastward." We can confirm this by our research on other 'fringe regions' of the oikumene.

${ }^{36}$ E.g., Novaesium, modern Neuss, was moved by Ptolemy from Gallia inferior into Germania magna. For an explanation and recalculation of Ptolemy's coordinates, see Tupikova-Geus 2014. 
material of merchants, soldiers, functionaries, and diplomats, ${ }^{37}$ comparisons with other Greek and Roman sources may sometimes be misleading. Literary sources are relatively uniform in regard to place-names, as they regularly employ the traditional names with which readers are familiar. By contrast, place-names in documentary sources were normally written down according to what the travellers heard during their journeys. Therefore, the linguistic analysis of Armenian place-names in Ptolemy must be carried out in different ways:

a) synchronically, i.e. comparing the contemporary testimonies in all languages,

b) diachronically, i.e. paying attention to the developments in the Armenian language (at least in Greco-Roman and Byzantine times), and

c) dialectally, i.e. allowing for some variations of place-names (or vice versa, for misidentification of similar toponyms).

The next step will indicate checking possible identifications of Ptolemy's toponyms according to the mathematical formulae of spherical trigonometry as outlined above in this paper.

To sum up: approaching Armenian toponyms in Ptolemy's Geography an interdisciplinary collaboration of Armenologists, historians, historical geographers, and mathematicians (specialised in spherical trigonometry or geodesy) is necessary. ${ }^{38}$ Such an approach will bring this unique chapter on Armenian history, surely not a 'parody', to fruition. ${ }^{39}$

BIBLIOGRAPHY

Adontz, N. (1970), Armenia in the Period of Justinian: The Political Conditions Based on the Naxarar System; Translated with Partial Revisions, a Bibliographical Note and Appendices by Nina G. Garsoïan, Lisboa.

Angeli Bertinelli, M. G. (2000), Traiano in Oriente: la conquista dell'Armenia, della Mesopotamia et dell'Assiria, in: J. González (ed.), Trajano emperador de Roma, Roma: 25-54.

Burri, R. (2013), Die Geographie des Ptolemaios im Spiegel der griechischen Handschriften, BerlinBoston.

Eremyan, S. T. (1963), Hayastan zst "Ašxarhac'oyc"” [Armenia according to the Ašxarhac'oyc'], Erevan.

Galichian, R. (2007), Countries South of the Caucasus in Medieval Maps: Armenia, Georgia and Azerbaijan, Erevan.

37 See Geus 2017b.

38 I do not share Licini's skeptical view: "As a result, the Ptolemaic map of the Caucasus is quite useless in the history of the Caucasus" (2017, 61; see also 74). Quite the contrary!

39 For the philological and historical interpretation of the Armenian toponyms, a lot of work has been done already, e.g., by Marquart 1901; Hübschmann 1904; Marquart 1928; Eremyan 1963; Manandian 1965; Hewsen 1965; Hewsen 1982; Hewsen 1990; Schmitt 2001; Harut 'yunyan 2001; see, for details, also Kiepert 1870; Garsoïan 1998; Geus 2017a. But if our hypothesis is correct, a whole new evaluation of the corpus of Armenian toponyms on the basis outlined above needs to be done. 


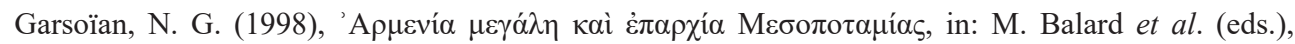
EYYYXIA: mélanges offerts à Hélène Ahrweiler, Paris: 239-264.

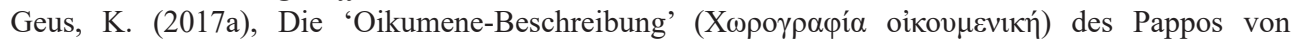
Alexandria und die armenische 'Welt-Schau' (Ašxarhac'oyc) des Movsēs von Chorene: zur Rezeption des Ptolemaios im Griechischen und Armenischen, in: R. Rollinger (ed.), Die Sicht auf die Welt zwischen Ost und West (750 v. Chr.-550 n. Chr.) / Looking at the World from the East and the West (750 BCE-550 CE), Wiesbaden: 81-93.

Geus, K. (2017b), Wer ist Marinos von Tyros? Zur Hauptquelle des Ptolemaios in seiner Geographie, Geographia antiqua 26: 13-22.

Geus, K., Tupikova, I. (2013a), The Circumference of the Earth and Ptolemy's World Map, Berlin.

Geus, K., Tupikova, I. (2013b), Von der Rheinmündung in den Finnischen Golf...: neue Ergebnisse zur Weltkarte des Ptolemaios, zur Kenntnis der Ostsee im Altertum und zur Flottenexpedition des Tiberius im Jahre 5 n. Chr., Geographia antiqua 22: 125-143.

Geus, K., Tupikova, I. (2019), Entdeckungsfahrten und Kartographie: Anmerkungen zu einer problembefrachteten Beziehung im Altertum, in: R. Schulz (ed.), Maritime Entdeckung und Expansion: Kontinuitäten, Parallelen und Brüche von der Antike bis in die Neuzeit, Berlin-Boston: $223-242$.

Harut'yunyan, B. (2001), Mec Hayk'i varča-k'alak'akan bažanman hamagark'n ost "Ašxarhac 'oyc "'-i Mas a [The System of Administrative and Political Division of Greater Armenia according to the First Part of the Ašxarhac 'oyc '], Erevan.

Harut'yunyan, B. H., Mkhitaryan, V. G. (2005), Hayastani patmut' yan atlas (Part 1), Erevan.

Hewsen, R. H. (1965), Armenia according to the AŠXARHAC'OYC', Revue des Études Armeniennes n.s. 2: 319-342.

Hewsen, R. H. (1982), Ptolemy's Chapter on Armenia: An Investigation of His Toponyms, Revue des Études Arméniennes 16: 111-150.

Hewsen, R. H. (1990), Armenia: A Historical Atlas, Cartographer-in-chief: Ch. C. Salvatico, ChicagoLondon.

Hübschmann, H. (1904), Die altarmenischen Ortsnamen: mit Beiträgen zur Topographie Armeniens und einer Karte, Sonderdruck aus dem 16. Band der Indogermanischen Forschungen von K. Brugmann und W. Streitberg, Straßburg.

Kiepert, H. (1870), Über die älteste Landes- und Volkgeschichte von Armenien, in: Monatsberichte der Königlich Preußischen Akademie der Wissenschaften zu Berlin (11. März 1869), Berlin: 216-243.

La Vaissière, É. de (2009), The Triple System of Orography in Ptolemy's Xinjiang, in: W. Sundermann, A. Hintze, F. de Bloia (eds.), Festschrift in Honour of Nicolas Sims-Williams, Wiesbaden: 527-536.

Licini, P. (2017), Surveying Georgia's Past: On the Use of Cartographic Sources for Caucasian History, Annali di Ca' Foscari. Serie orientale 53: 61-153.

Manandian, H. A. (1965), The Trade and Cities of Armenia in Relation to Ancient World Trade, transl. N. G. Garsoian, Lisboa.

Marquart, J. (1901), Ėrānšahr nach der Geographie des Ps. Moses Xorenac 'i. Mit historisch-kritischem Kommentar und historischen und topographischen Excursen, Berlin.

Marquart, J. (1928), Skizzen zur historischen Topographie und Geschichte von Kaukasien: Das Itinerar von Artaxata nach Armastica auf der römischen Weltkarte, Wien.

Mittenhuber, F. (2009), Text- und Kartentradition in der Geographie des Klaudios Ptolemaios: eine Geschichte der Kartenüberlieferung vom ptolemäischen Original bis in die Renaissance, Bern.

Mittenhuber, F. (2010), The Tradition of Texts and Maps in Ptolemy's Geography, in: A. Jones (ed.), Ptolemy in Perspective: Use and Criticism of His Work from Antiquity to the Nineteenth Century, New York-London-Heidelberg: 95-119.

Mouraviev, S. N. (1992), La transgression « Ptoléméenne » de la Caspienne (date: $\mathrm{IV}^{\mathrm{e}}-\mathrm{II}^{2}$ ss. av. J.-C.; maximum +10/+20); trois pièces du dossier, Geographia antiqua 1: 137-149.

Müller, K. (1901), Claudii Ptolemaei geographia e codicibus recognovit, prolegomenis, annotatione, indicibus, tabulis instruxit Carolus Müllerus, vol. II, Parisiis. 
Schmitt, R. (2001), On the Rendering of Compound and Multipartite Greek Toponyms in the Armenian 'Geography' of Ananias of Shirak, Orbis Terrarum 7: 175-184.

Shcheglov, D. A. (2016), The Accuracy of Ancient Cartography Reassessed: The Longitude Error in Ptolemy's Map, Isis 107: 687-706.

Shcheglov, D. A. (2018), The so-called itinerary stade and the Accuracy of Eratosthenes' Measurement of the Earth, Klio 101: 153-177.

Strobel, K. (2019), Kaiser Trajan. Epoche einer Weltgeschichte, Darmstadt.

Stückelberger, A., Graßhoff, G. (eds.) (2006), Klaudios Ptolemaios. Handbuch der Geographie, Griechisch-Deutsch, vol. I-II, Basel.

Toumanoff, C. (1963), Studies in Christian Caucasian History, Washington, D. C.

Tupikova, I. (2013), Ptolemy's Circumference of the Earth, in: M. F. Buchroithner (ed. on behalf of the International Cartographic Association), From Pole to Pole: Proceedings of the 26th International Cartographic Conference, Dresden, Germany, 25-30 August 2013 (s. pag.).

Tupikova, I. (2014), Ptolemy's Circumference of the Earth, Berlin.

Tupikova, I., Geus, K. (2014), The Location of Novaesium: A New Interpretation of Ptolemy's Coordinates, Orbis Terrarum 12: 293-309.

Tupikova, I., Geus, K. (forthcoming), Ptolemy's Geography and the Pitfalls of Statistical Analysis: A Study in 'Common Sense Geography', in: K. Geus, M. Thiering (eds. in association with V. Gysembergh and S. Lund Sørensen), Studies in 'Common Sense Geography': New Perspectives on Ancient Texts, Frankfurt-Bern-New York-Oxford.

Tupikova, I., Schemmel, M., Geus, K. (2014), Travelling along the Silk Road: A New Interpretation of Ptolemy's Coordinates, Berlin.

Wilberg, F. W. (1845), Claudii Ptolemaei geographiae libri octo. Graece et latine ad codicem manu scriptorum fidem edidit Dr. Frid. Guil. Wilberg, fasc. I-VI, Essendiae.

Winkler, G., Mittenhuber, F. (2009), Die Länderkarten Asiens, in: A. Stückelberger, F. Mittenhuber (eds.), Klaudios Ptolemaios: Handbuch der Geographie; Ergänzungsband mit einer Edition des Kanons bedeutender Städte, Basel: 282-289. 